\title{
Haplotype analysis and linkage disequilibrium for DGAT1
}

\author{
EVA M. STRUCKEN ${ }^{1,2}$, SIHAM RAHMATALLA ${ }^{1}$, DIRK-JAN DE KONING ${ }^{2}$ and GUDRUN
} A. BROCKMANN ${ }^{1}$

\begin{abstract}
'Breeding Biology and Molecular Genetics, Department for Crop and Animal Sciences, Faculty of Agriculture and Horticulture, Humboldt-Universität zu Berlin, Berlin, Germany, ${ }^{2}$ Genetics and Genomics, Roslin Institute and R(D)SVS, University of Edinburgh, Roslin, United Kingdom
\end{abstract}

\section{Abstract}

This study focused on haplotype effects and linkage disequilibrium (LD) for the K232A locus and the promoter VNTR in the DGAT1 gene. Analyses were carried out in three German Holstein Frisian populations (including 492, 305, and 518 animals) for milk yield, milk fat and protein yield, and milk fat and protein content. We found that effects of the promoter VNTR were not significant and explain only a small amount of the variation of the QTL on BTA14. Haplotype effects were less significant than the K232A locus by itself, but the haplotype containing the A allele of the K232A locus and allele 3 with five repeats of the promoter VNTR showed negative effects on protein content when paternally inherited, whereas the haplotype with the A allele and VNTR allele 2 (with six repeats) increased the protein content. Significant differences between these two haplotypes occurred for protein yield as well, pointing to a linked effect that is picked up by the haplotypes rather than a direct effect of the VNTR. The linkage disequilibrium, estimated by $D^{\prime}$, showed values between 0.29 and 0.59 which is unexpectedly low for a distance of $\sim 10 \mathrm{~kb}$. Only a very low correlation between the two loci was observed due to the almost similar frequencies of haplotypes containing the A or K allele of the K232A locus.

Keywords: German Holstein Frisian, DGAT1, haplotype, linkage disequilibrium

\section{Zusammenfassung}

\section{Haplotypenanalyse und Kopplungsungleichgewicht für DGAT1 in Holstein Populationen}

Die vorliegende Studie untersucht Haplotypeneffekte und das Kopplungsungleichgewicht (LD) für den K232A Polymorphismus und den Promoter-VNTR im DGAT1-Gen. Die Analysen von in drei Deutschen Holstein Frisian Populationen (mit 492, 305 und 518 Milchkühen) für Milchleistung, Milchfett- und Milchproteinmenge sowie Milchfett- und Milchproteingehalt durchgeführt. Wir konnten zeigen, dass die Effekte in den einzelnen Herden signifikant für den K232A Polymorphismus jedoch nicht signifikant für den Promoter VNTR sind, welcher somit nur einen kleinen Anteil an der Variation des QTLs auf BTA14 darstellt. Haplotypeneffekte sind weniger signifikant als der K232A Locus für sich genommen. Der Haplotyp, der das A-Allel des K232A Locus sowie Allel 3 des PromoterVNTRs mit fünf Wiederholungen enthält, hat negative Effekte auf den Proteingehalt, wenn er paternal vererbt wurde, wohingegen der Haplotyp mit Allel A und dem VNTR- 
Allel 2 mit sechs Wiederholungen den Proteingehalt steigert. Signifikante Unterschiede zwischen diesen Haplotypen treten ebenfalls für Proteinmenge auf. Diese Haplotypeneffekte deuten darauf hin, dass der VNTR nicht allein den Effekt erklären kann. Das Kopplungsungleichgewicht wurde durch $D^{\prime}$ bestimmt und zeigt Werte zwischen 0.29 und 0.59 , was für eine Distanz von $\sim 10 \mathrm{~kb}$ unerwartet niedrig ist. Die geringe Kopplung kann durch die beinahe gleichen Haplotypenfrequenzen, die entweder das A oder das K Allel des K232A Locus enthalten, erklärt werden.

Schlüsselwörter: Deutsche Holstein Frisian, DGAT1, Haplotyp, Kopplungsungleichgewicht

\section{Introduction}

Several studies showed an association between gene variants of the acylCoA:diacylglycerol acyltransferase 1 gene (DGAT1) on BTA14 and milk composition and quality. A nonsynonymous mutation (K232A) in exon 8 as well as a variable number of tandem repeats (VNTR) in the promoter region of DGAT1 showed impacts on fat and protein content as well as on fatty acid composition (WINTER et al. 2002, GRISART et al. 2002, THALLER et al. 2003, KÜHN et al. 2004, CITEK et al. 2007, RAHMATALLA et al. 2008). Significant dominance effects for the $\mathrm{K}$ allele as well as for allele 1 (seven repeats) and 5 (three repeats) of the VNTR on milk fat content have been reported only by KÜHN et al. (2007). Additional association studies investigated the effects of haplotypes considering the two loci and showed different effects on the traits depending on which VNTR allele was present (SANDERS et al. 2006, KÜHN et al. 2007). Furthermore, a high $D^{\prime}$ value of 0.98 between the two loci was presented for Holstein breeds (GAUTIER et al. 2007) which is expected for a distance of about $10 \mathrm{~kb}$. In the present study, we analyzed the two loci of the DGAT1 gene in three German Holstein Frisian herds with respect to dominance effects and the association of maternal and paternal inherited haplotypes with milk, fat and protein yield, and fat and protein content. Furthermore, linkage disequilibrium between the two loci was calculated.

\section{Material and methods}

Genotype and haplotype data for the DGAT1 K232A locus, the DGAT1 promoter VNTR, as well as haplotype information were taken from RAHMATALLA et al. (2008) where all three herds were analysed as one. The three herds were formerly selected independently. Herd 2 was selected for high protein yield. Even if no allele differences are seen on the analyzed DGAT1 polymorphisms, genome-wide differences are very likely, and therefore, this study treated the three herds separately. The alleles of the K232A mutation were denoted as $\mathrm{K}$ (Lysine) and A (Allanin). Alleles of the DGAT1 promoter VNTR were denoted as 1 to 5, where allele 1 has seven repeats, allele 2 six, allele 3 five, allele 4 four, and allele 5 three repeats, respectively. Haplotypes were denoted as amino acid variant $\mathrm{A}$ or $\mathrm{K}$ and the number of the VNTR allele, e.g. A2. For the estimation of genotype and haplotype effects, only genotypes and haplotypes represented by at least $10 \%$ of the animals were considered. Only complete records of milk production performance from the first to third lactation at the 305th day were considered. Thus, for the final analysis, herd 1 consisted of 
492 animals descending from 106 sires, herd 2 of 305 animals from 79 sires, and herd 3 of 518 animals from 145 sires. Animal-specific performance data were provided by VIT (Vereinigte Informationssysteme Tierhaltung w.V., Verden, Germany). Because we did not want to include corrections outside the herds, data analysis was based on herd specific yield deviation (YD) for every lactation corrected for calving season based on the VIT data. Other factors had no significant influence. The mean YD over the first three lactations was calculated as the measure for all three lactations.

Genotype and allele substitution effects as well as haplotype effects for both loci were modelled according to RAHMATALLA et al. (2008; model 2, 3, 4, and 5). The herd effect was tested including the herd as a fixed effect in model 2 of RAHMATALLA et al. (2008) and applied to a data set including all herds.

To show whether the haplotype as a combination of the two loci explains more variation than the single $\mathrm{K} 232 \mathrm{~A}$ locus following model was used:

$$
Y_{i j k l}=\mu+s_{i}+\mathrm{K}^{2} 32 \mathrm{~A}_{k}+\mathrm{HT}_{1}+e_{i j k l}
$$

where $Y_{i j k l}$ is the YD of daughter $j$ within sire $i, \mu$ is the overall mean of the herd, $s_{i}$ is the random effect of sire $i, \mathrm{~K}_{2} 32 \mathrm{~A}_{k}$ is the fixed effect of the DGAT1 K232A genotype $k$ (AA, KA, $\mathrm{KK}), \mathrm{HT}$, is the fixed effect of either the paternally or maternally inherited haplotype I and $e_{i j k}$ is the random residual effect.

All analyses were performed with the MIXED procedure of the SAS program version 9.2 (SAS 2008). Dominance values were estimated as the difference between the heterozygous and the mean of the homozygous genotypes for the DGAT1 K232A locus only. For estimating linkage disequilibrium (LD), $D^{\prime}$ (normalized LD between the two loci weighted by the product of allele frequencies), $r^{2}$ (pooled correlation between the two loci based on allele frequencies), and $x^{2}$ (chi-square statistic to test for independence between alleles at the two loci) were calculated for multiallelic loci according to ZHAO et al. (2007).

\section{Results}

The DGAT1 promoter VNTR was not in HWE, except for herd 2. The deviation from HWE for the VNTR locus might be due to a lower animal number or the presence of family relationships. Genotype and allele frequencies over $10 \%$ are shown in Table A1. Herd as a fixed effect in an analysis over all three herds did not show any significant influence on the DGAT1 loci.

However, slightly different effects were found between the herds if they were analysed separately. Paternal as well as maternal haplotype K3 showed a positive effect on the content traits in all three herds. The effects of the haplotype $\mathrm{K} 3$ showed deviations from additive effects in such way that the sum of the effect of the $K$ allele and the VNTR allele 3 on fat content was higher than the effect of haplotype K3. Similar deviations were observed for other traits.

Model 1 was used to show whether the single K232A locus or the haplotype as a combination of the K232A and VNTR polymorphism has a greater effect. Including the $\mathrm{K} 232 \mathrm{~A}$ locus revealed that the haplotypes were almost always insignificant and explained 
less of the variance then the K232A locus on its own (Table 1). This shows that the influence of the VNTR can be assumed as very small.

Table 1

$P$-values for effects of the K232A locus and haplotypes (HT)

P-Werte für Effekte des K232A Locus und Haplotypen (HT)

\begin{tabular}{lccccc}
\hline Trait & Herd & $\mathrm{K}^{2} 32 \mathrm{~A}^{1}$ & Maternal HT & $\mathrm{K} 232 \mathrm{~A}^{2}$ & Paternal HT \\
\hline $\mathrm{YD}_{\text {mkg }}$ & 1 & $<0.0001$ & 0.09 & 0.01 & 0.27 \\
& 2 & 0.07 & 0.37 & 0.0004 & 0.20 \\
& 3 & 0.05 & 0.94 & 0.01 & 0.08 \\
$\mathrm{YD}_{\mathrm{fkg}}$ & 1 & 0.003 & 0.34 & 0.35 & 0.29 \\
& 2 & 0.24 & 0.28 & 0.65 & 0.14 \\
& 3 & 0.002 & 0.50 & 0.003 & 0.08 \\
$\mathrm{YD}_{\mathrm{f} \%}$ & 1 & $<0.0001$ & 0.08 & $<0.0001$ & 0.26 \\
& 2 & $<0.0001$ & 0.76 & $<0.0001$ & 0.46 \\
& 3 & $<0.0001$ & 0.59 & $<0.0001$ & 0.99 \\
$\mathrm{YD}_{\text {pkg }}$ & 1 & 0.06 & 0.07 & 0.30 & 0.71 \\
& 2 & 0.83 & 0.42 & 0.03 & 0.29 \\
& 3 & 0.13 & 0.93 & 0.04 & 0.04 \\
$\mathrm{YD}_{\mathrm{p} \%}$ & 1 & $<0.0001$ & 0.59 & $<0.0001$ & 0.54 \\
& 2 & $<0.0001$ & 0.77 & $<0.0001$ & 0.06 \\
& 3 & 0.01 & 0.70 & 0.0001 & 0.45 \\
\hline
\end{tabular}

${ }^{1} P$-value for the K232A locus in model 1 , when the maternal HT was used, ${ }^{2} P$-value for the K232A locus in model 1 , when the paternal HT was used

Table 2

Linkage Disequilibrium between the two multiallelic loci in DGAT1 (K232A and VNTR) for three Holstein populations

Kopplungsungleichgewicht zwischen den beiden multiallelen Loci im DGAT1-Gen (K232A und VNTR) für drei Holstein Populationen

\begin{tabular}{lccccccc}
\hline & \multicolumn{3}{c}{ Maternal HT } & Herd & \multicolumn{3}{c}{ Paternal HT } \\
& 1 & 2 & 3 & 1 & 2 & 3 \\
\hline $\mathrm{n}$ & 507 & 327 & 546 & 507 & 327 & 546 \\
$D^{\prime}$ & 0.34 & 0.36 & 0.51 & 0.29 & 0.59 & 0.46 \\
$\mathrm{r}^{2}$ & 0.05 & 0.05 & 0.10 & 0.06 & 0.15 & 0.08 \\
$X^{2}$ & 116.75 & 87.03 & 170.30 & 88.50 & 180.81 & 178.50 \\
$P$-value & $<0.0001$ & $<0.0001$ & $<0.0001$ & $<0.0001$ & $<0.0001$ & $<0.0001$ \\
\hline
\end{tabular}

The $\mathrm{K}$ allele showed significant dominance in all herds on all traits except for fat yield. Only herd 3 showed a significant dominance effect for the $\mathrm{K}$ allele on fat yield. Furthermore, we report a dominance effect of the $A$ allele on protein yield for herd 3 $(P=0.0004)$, which has to be proven by further analysis.

Relatively low $D^{\prime}$ values between 0.29 and 0.59 were estimated as a measurement of $L D$, and in addition very low $r^{2}$ values were observed. All estimates were highly significant with 4 degrees of freedom (Table 2). 


\section{Discussion}

Frequencies of both DGAT1 polymorphisms fulfilled the expectations for Holstein Frisians (SANDERS et al. 2006, GAUTIER et al. 2007, KÜHN et al. 2007). The effects of the K232A locus as reported for Holstein Frisian breeds could be confirmed for all three herds (KÜHN et al. 2007, RAHMATALLA et al. 2008). Effects reported for the VNTR locus on the content traits could not be confirmed. A major effect for allele 1 (with seven repeats) was reported by KÜHN et al. (2007). We did not find allele 1 with a sufficiently high frequency in our population. The missing VNTR allele 1, and thus, its absent allele effect might be restricted to this data set.

Taking the K232A locus into account, the VNTR locus alone as well as the haplotypes showed no significant effects, suggesting only a very small or no contribution of the promoter VNTR to the variation explained by the QTL on BTA14, which does not reach significance due to the smaller animal numbers in the separate herds. Nevertheless, excluding the K232A locus (model 3 by RAHMATALLA et al. [2008]), significant differences between the paternal haplotypes $A 3$ and $A 2$ were found in two herds. Effects of the haplotypes followed in most cases the reported effects for the K232A alleles (Figure A1, Table A2).

Significant positive dominance effects of the Lysine DGAT1 variant $(\mathrm{K})$ on fat content can be confirmed (KÜHN et al. 2007). A striking point is the significant dominance effect of the Alanin variant (A) for protein yield in herd 3 while for herd 1 and 2 dominance of the $\mathrm{K}$ allele is indicated (Figure $\mathrm{A} 1$, Table $\mathrm{A} 3$ ).

In our populations, the K232A alleles occurred with frequencies up to $18 \%$ with other VNTR alleles than allele 3 and did not show one exclusive haplotype, resulting in relatively low $D^{\prime}$ values compared to GAUTIER et al. (2007). Nevertheless, we showed that the K232A alleles were associated with allele 3 of the VNTR more frequently than with other VNTR alleles. The low $r^{2}$ values result from the almost equivalent frequency of $A 3$ and K3 haplotypes. The genetic background of herd 2, which had been selected for high protein yield, seems to have no influence on the DGAT1 effects. However, herd 3 shows deviation from the other two herds regarding dominance effects which can not be explained without more information about the population. This might reflect interaction of the DGAT1 locus with other regions in the genome. Unidentified population substructures as a result of the population history including gene flow and founder effects could cause the deviation in haplotype frequency. The determination of the LD between the biallelic K232A polymorphism and the multiallelic VNTR depends on the representative sample of animals of the population. The three herds in the present examination represent an unbiased sample with $D^{\prime}$ estimates between 0.29 and 0.59 for the LD.

\section{Acknowledgements}

E. M. Strucken acknowledges the SABRETRAIN project (EC Contract number MEST-CT2005-020558) funded by Marie Curie Host Fellowship for Early Stage Research Training. S. Rahmatalla acknowledges support from the DAAD. D. J. de Koning acknowledges the BBSRC for contributions through the Institute Strategic Programme Grant. 


\section{References}

Citek J, Rehout V, Hradecka E, Vecerek L, Panicke L (2007) The breeding values of German Holstein sires and the DGAT1 polymorphism. Arch Tierz 50, 136-46

Gautier M, Capitan A, Fritz S, Eggen A, Boichard D, Druet T (2007) Characterization of the DGAT1 K232A and variable number of tandem repeat polymorphisms in French dairy cattle. J Dairy Sci 90, 2980-8

Grisart B, Coppieters W, Farnir F, Karim L, Ford C, Berzi P, Cambisano N, Mni M, Reid S, Simon P, Spelman R, Georges M, Snell R (2002) Positional candidate cloning of a QTL in dairy cattle: identification of a missense mutation in the bovine DGAT1 gene with major effect on milk yield and composition. Genome Res 12, 222-31

Kühn C, Thaller G, Winter A, Bininda-Emounds OR, Kaupe B, Erhardt G, Bennewitz J, Schwerin M, Fries R (2004) Evidence for multiple alleles at the DGAT1 locus better explains a quantitative trait locus with major effects on milk fat content in cattle. Genetics 167,1873-81

Kuehn C, Edel C, Weikard R, Thaller G (2007) Dominance and parent-of-origin effects of coding and noncoding alleles at the acylCoA-diacylglycerol-acyltransferase (DGAT1) gene on milk production traits in German Holstein cows. BMC Genet 8, 62

Rahmatalla S, Mueller U, Strucken EM, Brockmann G (2008) Characterization of DGAT1-variants in German Holstein cattle under production conditions. Züchtungsk 80, 473-84 [in German]

Sanders K, Bennewitz J, Reinsch N, Thaller G, Prinzenberg EM, Kuhn C, Kalm E (2006) Characterization of the DGAT1 mutations and the CSN1S1 promoter in the German Angeln dairy cattle population. J Dairy Sci 89, 3164-74

Thaller G, Kramer W, Winter A, Kaupe B, Erhardt G, Fries R (2003) Effects of DGAT1 variants on milk production traits in German cattle breeds. J Anim Sci 81, 1911-8

Winter A, Kramer W, Werner FA, Kollers S, Kata S, Durstewitz G, Buitkamp J, Womack JE, Thaller G, Fries R (2002) Association of a lysine-232/alanine polymorphism in a bovine gene encoding acylCoA:diacylglycerol acyltransferase (DGAT1) with variation at a quantitative trait locus for milk fat content. Proc Natl Acad Sci USA 99, 9300-5

Zhao H, Nettleton D, Dekkers JC (2007) Evaluation of linkage disequilibrium measures between multiallelic markers as predictors of linkage disequilibrium between single nucleotide polymorphisms. Genet Res 89, 1-6

\section{Appendix}

Table A1

Genotype (GT), allele and haplotype (HT) frequencies with more than $10 \%$ for the two loci in DGAT1 (K232A and VNTR) in three Holstein populations

Genotypen (GT), Allele- und Haplotypenfrequenzen (HT) der beiden Loci im DGAT1-Gen (K232A und VNTR) mit mehr als $10 \%$ in drei Holstein Frisian Populationen

\begin{tabular}{|c|c|c|c|c|c|c|c|c|}
\hline \multirow[b]{3}{*}{ Locus } & \multicolumn{8}{|c|}{ Herd } \\
\hline & & 1 & 2 & 3 & & 1 & 2 & 3 \\
\hline & GT & \multicolumn{3}{|c|}{ Genotype frequencies } & Allele & \multicolumn{3}{|c|}{ Allele frequencies } \\
\hline \multirow[t]{3}{*}{$\mathrm{K} 232 \mathrm{~A}$} & $\mathrm{AA}$ & 0.29 & 0.30 & 0.32 & $A$ & 0.54 & 0.56 & 0.57 \\
\hline & KA & 0.50 & 0.52 & 0.49 & & & & \\
\hline & KK & 0.21 & 0.18 & 0.18 & K & 0.46 & 0.44 & 0.43 \\
\hline \multirow[t]{6}{*}{ VNTR } & & & & & 5 & 0.02 & 0.01 & 0.02 \\
\hline & 34 & 0.28 & 0.23 & 0.19 & 4 & 0.22 & 0.17 & 0.15 \\
\hline & 33 & 0.39 & 0.33 & 0.37 & 3 & 0.64 & 0.60 & 0.62 \\
\hline & 23 & 0.19 & 0.26 & 0.24 & 2 & 0.11 & 0.18 & 0.17 \\
\hline & & & & & 1 & 0.002 & 0.03 & 0.05 \\
\hline & $\mathrm{HT}^{*}$ & \multicolumn{3}{|c|}{ Maternal HT frequency } & $\mathrm{HT}^{*}$ & \multicolumn{3}{|c|}{ Paternal HT frequency } \\
\hline \multirow[t]{6}{*}{$\mathrm{HT}$} & A4 & 0.15 & 0.13 & 0.13 & A4 & 0.13 & 0.09 & 0.07 \\
\hline & A3 & 0.27 & 0.25 & 0.25 & A3 & 0.34 & 0.28 & 0.32 \\
\hline & $\mathrm{A} 2$ & 0.11 & 0.12 & 0.15 & $\mathrm{~A} 2$ & 0.05 & 0.18 & 0.12 \\
\hline & K4 & 0.11 & 0.10 & 0.06 & K4 & 0.06 & 0.03 & 0.03 \\
\hline & K3 & 0.27 & 0.28 & 0.30 & K3 & 0.39 & 0.41 & 0.39 \\
\hline & $\mathrm{K} 2$ & 0.06 & 0.06 & 0.04 & $\mathrm{~K} 2$ & 0.01 & 0.009 & 0.02 \\
\hline
\end{tabular}

*The symbol of the haplotype consists of the allele at the K232A locus followed by the allele number of the VNTR allele. 
Table A2

Significant trait differences between haplotype groups $(\mathrm{HT})$ for maternal and paternal haplotypes for all herds (LSM $\pm \mathrm{SE}$, ( $P$-value))

Signifikante Unterschiede zwischen Haplotypengruppen (HT) für maternale und paternal Haplotypen für alle drei Herden (LSM $\pm S E$, (P-Wert))

\begin{tabular}{|c|c|c|c|c|c|c|c|}
\hline \multirow{4}{*}{$\frac{\text { Trait }}{\mathrm{YD}_{\mathrm{mkg}}}$} & \multirow{4}{*}{$\frac{\mathrm{HT}}{\mathrm{A} 4-\mathrm{K} 3}$} & \multicolumn{3}{|c|}{ Herd } & \multicolumn{3}{|c|}{ Herd } \\
\hline & & 1 & 2 & 3 & 1 & 2 & 3 \\
\hline & & \multicolumn{3}{|c|}{ Maternal HT differences } & \multicolumn{3}{|c|}{ Paternal HT differences } \\
\hline & & - & $694.40 \pm 21.76^{*}$ & $454.94 \pm 173.27^{*}$ & $365.27 \pm 153.18^{*}$ & - & - \\
\hline & A3-K3 & $389.40 \pm 126.27^{*}$ & $397.33 \pm 80.84$ & $350.30 \pm 142.22$ & $597.37 \pm 113.73^{* * *}$ & - & $401.36 \pm 128.52^{* *}$ \\
\hline & $\mathrm{A} 2-\mathrm{K} 3$ & $692.86 \pm 164.69^{* * *}$ & $738.90 \pm 28.30^{* *}$ & $390.54 \pm 166.42$ & - & - & - \\
\hline$Y_{\text {fkg }}$ & $\mathrm{A} 2-\mathrm{K} 3$ & - & - & $-16.65 \pm 5.64^{*}$ & $-16.49 \pm 6.13^{*}$ & - & $-24.74 \pm 6.24^{* * *}$ \\
\hline \multirow[t]{5}{*}{$Y D_{f \%}$} & A4-K3 & $-0.27 \pm 0.06^{* * *}$ & $-0.28 \pm 0.07^{* *}$ & $-0.30 \pm 0.06^{* * *}$ & $-0.41 \pm 0.06^{* * *}$ & - & - \\
\hline & A3-K4 & - & $-0.30 \pm 0.08^{* *}$ & - & - & - & - \\
\hline & A3-K3 & $-0.24 \pm 0.05^{* * *}$ & $-0.25 \pm 0.06^{* * *}$ & $-0.30 \pm 0.05^{* * *}$ & $-0.40 \pm 0.05^{* * *}$ & $-0.22 \pm 0.06^{* * *}$ & $-0.31 \pm 0.04^{* * *}$ \\
\hline & $\mathrm{A} 2-\mathrm{K} 4$ & $-0.23 \pm 0.08^{*}$ & $-0.34 \pm 0.10^{* *}$ & - & - & - & - \\
\hline & $\mathrm{A} 2-\mathrm{K} 3$ & $-0.33 \pm 0.07^{* * *}$ & $-0.28 \pm 0.08^{* *}$ & $-0.40 \pm 0.05^{* * *}$ & - & $-0.23 \pm 0.08^{* *}$ & $-0.30 \pm 0.06^{* * *}$ \\
\hline \multirow[t]{3}{*}{$Y D_{p k g}$} & A3-K3 & - & - & - & $9.37 \pm 3.70^{*}$ & - & $10.30 \pm 3.92^{*}$ \\
\hline & $\mathrm{A} 2-\mathrm{K} 3$ & $17.34 \pm 5.08^{* *}$ & - & - & - & - & - \\
\hline & $\mathrm{A} 3-\mathrm{A} 2$ & - & - & - & - & - & $13.98 \pm 5.53^{*}$ \\
\hline \multirow[t]{4}{*}{$Y D_{p} \%$} & A4-K3 & $-0.09 \pm 0.02^{* * *}$ & $-0.09 \pm 0.03^{*}$ & $-0.07 \pm 0.02^{* *}$ & $-0.10 \pm 0.03^{* *}$ & - & - \\
\hline & A3-K3 & $-0.07 \pm 0.02^{* *}$ & $-0.08 \pm 0.03^{*}$ & $-0.07 \pm 0.02^{* *}$ & $-0.12 \pm 0.02^{* * *}$ & $-0.11 \pm 0.03^{* * *}$ & - \\
\hline & $\mathrm{A} 2-\mathrm{K} 3$ & $-0.08 \pm 0.03^{*}$ & $-0.14 \pm 0.03^{* * *}$ & $-0.08 \pm 0.02^{* * *}$ & - & - & - \\
\hline & $\mathrm{A} 3-\mathrm{A} 2$ & - & - & - & - & $-0.09 \pm 0.03^{* *}$ & - \\
\hline
\end{tabular}

*differences statistically significant at $P \leq 0.05, \quad{ }^{* *}$ differences statistically significant at $P \leq 0.01, \quad{ }^{* *}$ differences statistically significant at $P \leq 0.001$

Table A3

Dominance values ( $\pm \mathrm{SE}$, (P-value)) for the DGAT1 K232A locus in three Holstein Frisian herds Dominanzwerte ( $\pm S E$, (P-Wert)) für den DGAT1 K232A Locus in drei Holstein Frisian Herden

\begin{tabular}{|c|c|c|c|}
\hline \multirow{2}{*}{ Trait } & \multicolumn{3}{|c|}{ Herd } \\
\hline & 1 & 2 & 3 \\
\hline$\overline{Y D_{\text {mkg }}}$ & $-80.32 \pm 64.05^{* * *}$ & $-187.60 \pm 95.34^{* * *}$ & $-22.13 \pm 69.43^{* * *}$ \\
\hline $\mathrm{YD}_{\mathrm{fkg}}$ & $3.35 \pm 2.49$ & $0.57 \pm 3.53$ & $4.48 \pm 2.33^{*}$ \\
\hline $\mathrm{YD}_{\mathrm{f} \%}$ & $0.07 \pm 0.02^{* * *}$ & $0.10 \pm 0.03^{* * *}$ & $0.06 \pm 0.02^{* * *}$ \\
\hline$Y D_{p k g}$ & $-0.50 \pm 2.00^{* *}$ & $-3.03 \pm 2.99 * *$ & $0.92 \pm 2.15^{* * * *}$ \\
\hline$Y D_{p} \%$ & $0.02 \pm 0.01^{* * *}$ & $0.04 \pm 0.01^{* *}$ & $0.02 \pm 0.01^{* * *}$ \\
\hline
\end{tabular}

*differences statistically significant at $P \leq 0.05, \quad{ }^{* *}$ differences statistically significant at $P \leq 0.01, \quad{ }^{* * *}$ differences statistically significant at $P \leq 0.001$ 

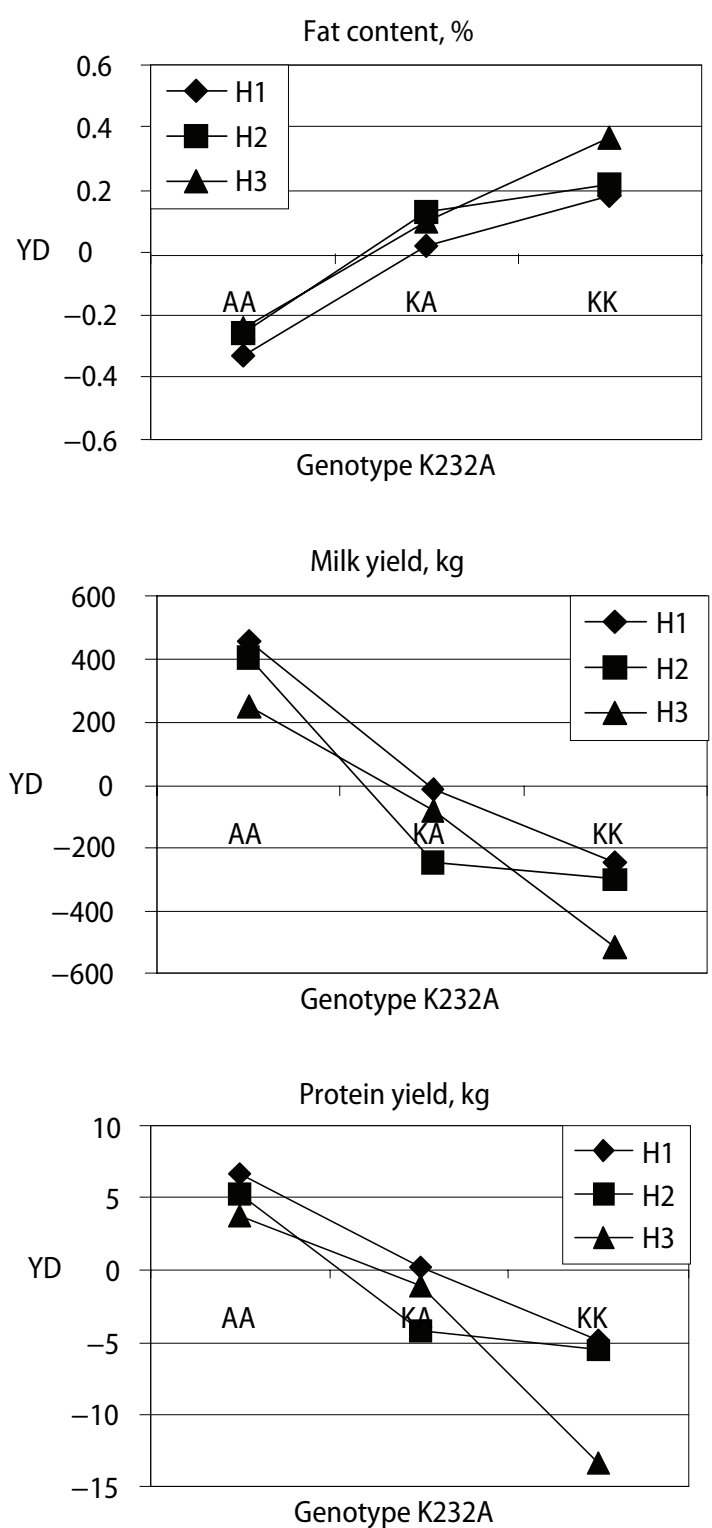

Figure A1

Least square means (LSM) of the yield deviation (YD) for the K232A genotypes in the three herds $(\mathrm{H} 1=$ herd $1 ; \mathrm{H} 2=$ herd $2 ; \mathrm{H} 3=$ herd 3). Significant dominance effects were observed for the $\mathrm{K}$ allele except on fat yield. Herd 3 showed dominance effect on protein yield for the A allele.

Least square means (LSM) für die Mengenabweichung des K232A Genotyps in drei Herden ( $H 1=$ Herde 1; $\mathrm{H} 2=$ Herde 2; $\mathrm{H3}=$ Herde 3). Signifikante Dominanzeffekte konnten für das $K$-Allel beobachtet werden außer für Fettmenge. In Herde 3 konnte außerdem ein Dominanzeffekt auf Proteinmenge für das A-Allel gezeigt werden. 

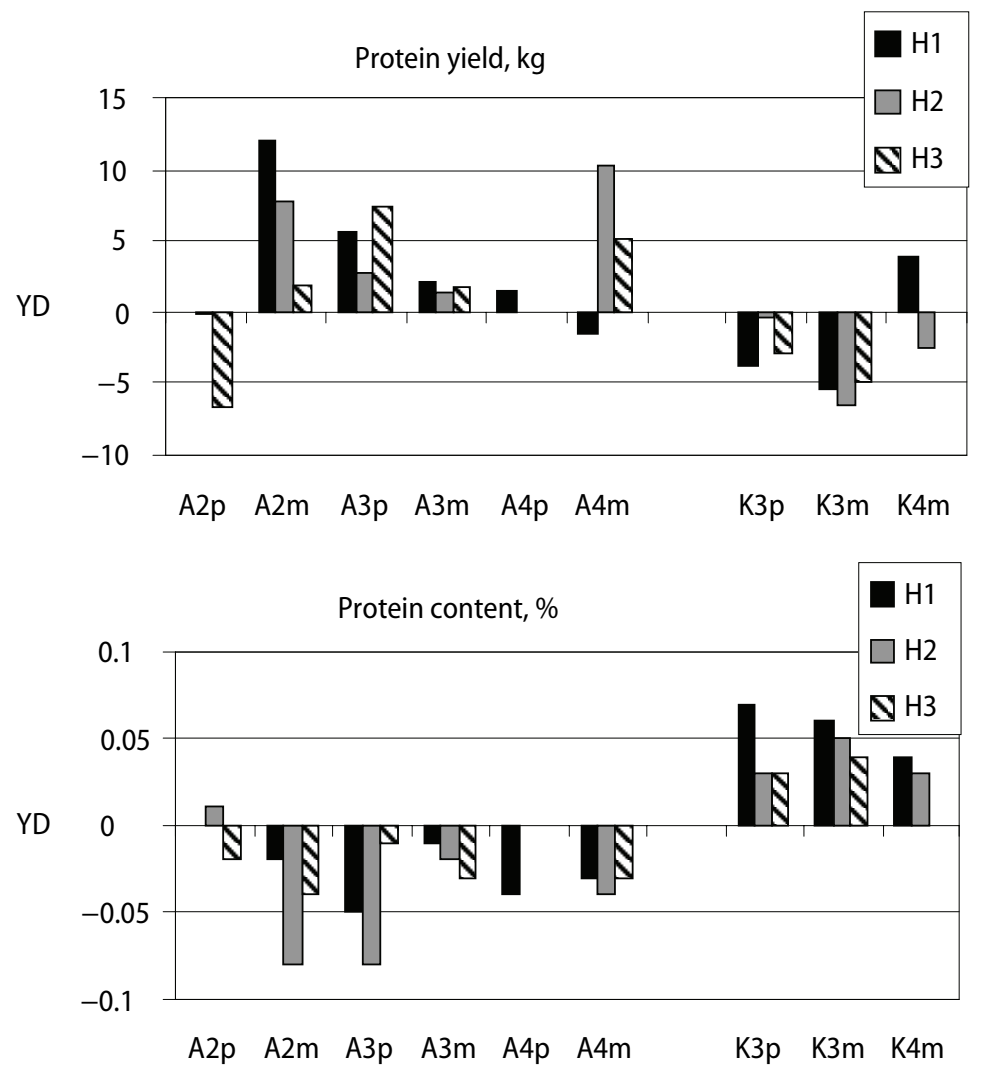

Figure A2

Differences between haplotype effects of DGAT1 (K232A and VNTR locus) in three herds ( $\mathrm{H} 1=$ herd $1 ; \mathrm{H} 2=$ herd 2; $\mathrm{H} 3=$ herd 3). Differences between $\mathrm{A} 3$ and $\mathrm{A} 4$ were significant for paternally (p) inherited haplotypes in herd 3 for protein yield and in herd 2 for protein content. All other significant differences occurred between haplotypes containing an $\mathrm{A}$ or a $\mathrm{K}$ allele and effects followed the observed allele effects of the K232A locus.

Unterschiede zwischen Haplotypeneffekten des DGAT1-Gens (K232A und VNTR) in drei Herden (H1=Herde 1; $H 2=$ Herde 2; $\mathrm{H3}=$ Herde 3). Differenzen zwischen $A 3$ und $A 4$ waren signifikant für den paternal (p) vererbten Haplotyp für Proteinmenge in Herde 3 und für Proteingehalt in Herde 2. Alle anderen signifikanten Unterschede traten zwischen Haplotypen auf, die entweder ein A oder ein K Allel trugen. Die Effekte folgten den beobachteten Alleleffekten des K232A Lokus.

Corresponding author:

\section{GUDRUN A. BROCKMANN}

email: gudrun.brockmann@agrar.hu-berlin.de

Breeding Biology and Molecular Genetics, Department for Crop and Animal Sciences, Faculty of Agriculture and Horticulture, Humboldt-Universität zu Berlin, Invalidenstraße 42, 10115 Berlin, Germany 